\title{
Selectivity of post-emergence herbicides to crambe $^{1}$
}

\section{Seletividade de herbicidas aplicados em pós-emergência da cultura do crambe}

\author{
José Fernando Jurca Grigolli
}

\begin{abstract}
Crambe is a dedicated oilseed crop suitable for production of industrial feedstocks. Due to the lack of information of post-emergent herbicides, the aim of this study was to evaluate the selectivity of post-emergence herbicides to crambe. The experiment was conducted in Maracaju, MS, Brazil, in 2013. Clethodim (120 $\mathrm{g} \mathrm{ha}^{-1}$ a.i.), haloxyfop-p-methyl (63.35 $\mathrm{g} \mathrm{ha}^{-1}$ a.i.), fomesafen + fluazifop-p-butil $\left(125+125 \mathrm{~g} \mathrm{ha}^{-1}\right.$ a.i. $)$, fomesafen + fluazifop-p-butil (187.5 + 187.5 $g \mathrm{gh}^{-1}$ a.i.), nicosulfuron $\left(45 \mathrm{~g} \mathrm{ha}^{-1}\right.$ a.i.) herbicides without and with mineral oil, and a control without herbicide application were assessed. Evaluations were performed 7, 14, 21 and 28 days after herbicide application based on the percentage of crambe plants with visual phytotoxicity, on the percentage of dead plants caused by herbicides, and the grain yield. In general, mineral oil increased the phytotoxic effects of herbicides on crambe plants when sprayed post-emergence. The mineral oil addition to haloxyfop-p-methyl increased the phytotoxicity to crambe plants. The herbicide fomesafen + fluazifop-p-butil and nicosulfuron were harmful to crambe plants with or without mineral oil, and clethodim (with and without mineral oil) and haloxyfop-p-methyl (without mineral oil) were harmless to crambe plants and can be used on post-emergence.
\end{abstract}

Keywords: Crambe abysinica; weed; phytotoxicity

Resumo - O crambe é uma oleaginosa indicada para a produção de matérias-primas industriais. Devido à falta de informação sobre herbicidas pós-emergentes para o controle de plantas daninhas, o objetivo deste trabalho foi avaliar a seletividade de herbicidas aplicados em pós-emergência na cultura do crambe. O experimento foi conduzido em Maracaju, MS, Brasil, no ano de 2013. Os herbicidas clethodim (120 g ha $\mathrm{g}^{-1}$ i.a.), haloxyfop-p-methyl $\left(63,35 \mathrm{~g} \mathrm{ha}^{-1}\right.$ i.a.), fomesafen + fluazifop-p-butil (125 + $125 \mathrm{~g} \mathrm{ha}^{-1}$ i.a.), fomesafen + fluazifop-p-butil $\left(187,5+187,5 \mathrm{~g} \mathrm{ha}^{-1}\right.$ i.a. $)$, nicosulfuron ( $45 \mathrm{~g} \mathrm{ha}^{-1}$ i.a.) foram avaliados com e sem óleo mineral, além de uma testemunha sem herbicida. As avaliações foram realizadas 7, 14, 21 e 28 dias após a aplicação dos tratamentos, baseando-se na porcentagem de plantas de crambe com sintomas visuais de fitointoxicação, na porcentagem de plantas mortas pelos herbicidas, e no rendimento de grãos. A adição do óleo mineral aumentou os efeitos fitotóxicos dos herbicidas nas plantas de crambe quando aplicados em pós-emergência. $\mathrm{O}$ óleo mineral adicionado ao herbicida haloxyfop-p-methyl aumentou a fitotoxicidade nas plantas de crambe. Os herbicidas fomesafen + fluazifop-p-butil e nicosulfuron não foram seletivos ao crambe com e sem óleo mineral, enquanto clethodim (com e sem óleo mineral) e haloxyfop-p-methyl (sem óleo mineral) foram seletivos ao crambe quando aplicados em pós-emergência.

Palavras-chaves: Crambe abyssinica; planta daninha; fitotoxicidade

\footnotetext{
${ }^{1}$ Received for publication on 18/03/2014 and approved on 25/08/2015.

${ }^{2}$ Plant Protection Researcher, Fundação MS, Caixa Postal 137, Maracaju, MS, 79150-000, fernando@fundacaoms.org.br.
} 


\section{Introduction}

Crambe (Crambe abyssinica Hoechst. Ex R.E.Fries) is a dedicated oilseed crop suitable for production of industrial feedstocks, producing an average grain yield of $1507 \mathrm{~kg} \mathrm{ha}$ ${ }^{1}$ in Brazil, which has 34\% oil content (Jasper et al., 2010). This crop has been an option for crop rotation system in the Midwest region of Brazil, due to its short cycle, tolerance to drought, and low temperatures (Fontana et al., 1998).

This plant has an annual cycle, height between 70 and $90 \mathrm{~cm}$, flowering 35 days after sowing, and its seeds are characterized by being round and covered by a husk ash. Its origin is Mediterranean, which has been cultivated in some tropical and subtropical regions for industrial interests in the oil extracted from its seeds, recently used for biodiesel production (Roscoe et al., 2010; Carneiro et al., 2009).

Crambe has some good agronomic properties, such as potential for phytoremediation of heavy metal contaminated soils and sediments (Chhikara et al., 2012) and tolerance to abiotic stress such as reduction of soil nematodes, which make it easily accepted by commercial production after improvement (Li et al., 2013). The weed control on crambe is important, such as in any other agricultural species, for the success of the activity. Weeds play an important role in the crop establishment, and crambe has a slow initial development, and it is extremely sensitive to competition caused by weeds (Endres; Schatz, 1993).

There are no registered herbicides for crambe in Brazil, committing the weed management on this crop. Due to great potential of crambe for some regions in Brazil, and the lack of information on the selectivity of postemergence herbicides, the purpose of this study was to evaluate the selectivity of postemergence herbicides to crambe.

\section{Material and Methods}

The experiment was carried out in an experimental area of the Fundação MS, in
Maracaju, state of Mato Grosso do Sul, Brazil, from April to August 2013. The experimental area was located at latitude $21^{\circ} 37^{\prime} 57^{\prime \prime}$ 'South, longitude $55^{\circ} 08^{\prime} 42^{\prime \prime}$ 'West, and altitude $384 \mathrm{~m}$ asl.

The experiment was arranged in a randomized block design in split plots with 12 treatments $(6$ herbicides x 2 without and with mineral oil) and five replications. The herbicides clethodim $\left(120 \mathrm{~g} \mathrm{ha}^{-1}\right.$ a.i. $)$, haloxyfop-p-methyl (63.35 g ha ${ }^{-1}$ a.i.), fomesafen + fluazifop-p-butil $\left(125+125 \mathrm{~g} \mathrm{ha}^{-1}\right.$ a.i.), fomesafen + fluazifop-p-butil (187.5 + $187.5 \mathrm{~g} \mathrm{ha}^{-1}$ a.i.), nicosulfuron (45 $\mathrm{g} \mathrm{ha}^{-1}$ a.i.), and a control without herbicide application were assessed without and with mineral oil. It was used the mineral oil Dash ${ }^{\circledR}\left(0.5 \mathrm{~L} \mathrm{ha}^{-1}\right)$.

Sowing was done mechanically on April 06, 2013, with an average of 15 plants per meter. The crambe cultivar used was FMS Brilhante. A total area of $2,100 \mathrm{~m}^{2}$ was divided into sixty plots, each of which consisted of seven 10-m rows, spaced $0.50 \mathrm{~m}$ apart $\left(35 \mathrm{~m}^{2}\right)$. The three central plant rows per plot were evaluated, excluding two meters from wither end of the rows.

Due to the low nutritional requirement of the crop and its high potential for utilization of residual fertilization, crambe has not shown significant responses to NPK fertilization (Broch and Roscoe, 2010). Thus, fertilization was not realized, the previous crop was soybean, and the soil was prepared on a conservation tillage system.

Insecticide and fungicide were not applied during the experiment, and herbicide application was accomplished on May 27, 2013 (plants in full bloom), starting at 07:12 am, using a constant pressurized sprayer $\left(\mathrm{CO}_{2}\right)$, equipped with a six-nozzle bar type TJ 06 $11002,0.5 \mathrm{~m}$ apart, and calibrated with $160 \mathrm{~L}$ $\mathrm{ha}^{-1}$. Conditions during herbicide application were $24.8{ }^{\circ} \mathrm{C}, 79 \%$ relative humidity, and $0.3 \mathrm{~m}$ $\mathrm{s}^{-1}$ wind speed.

Evaluations were performed 7, 14, 21 and 28 days after herbicide application (DAA) based on the percentage of crambe plants with 
visual phytotoxicity, and on the percentage of dead plants caused by herbicides. Grain yield was also evaluated, harvesting mechanically three 7-m rows of each plot. The data was subjected to ANOVA using Assistat Software (Silva and Azevedo, 2002) and treatment means were compared by Tukey test $(\mathrm{p}<0.05)$.

\section{Results and Discussion}

In the evaluations of the percentage of crambe plants with visual symptoms of phytotoxicity by herbicides, it was observed that in all evaluations herbicide fomesafen + fluazifop-p-butil on both dosages showed $100 \%$ of plants with symptoms, indicating that this herbicide should not be used on post-emergence of crambe (Table 1). The herbicide nicosulfuron showed pronounced phytotoxicity time passed, reaching $95.5 \%$ of crambe plants with symptoms of phytotoxicity at 28 DAA (Table 1). At 7 and 14 DAA, the herbicides haloxyfopp-methyl and clethodim showed the lowest phytotoxicity, whereas 21 and 28 DAA was the herbicide clethodim with the lowest values (Table 1). The addition of mineral oil showed a significantly increase on the percentage of plants with symptoms of phytotoxicity from 14 DAA (Table 1). It was observed significant differences on the interaction between mineral oil and plants with symptoms of phytotoxicity 14,21 , and 28 DAA.

Table 1. Herbicide injury (\%) on Crambe abyssinica plants evaluated during four periods after application. Maracaju, MS, Brazil, 2013.

\begin{tabular}{|c|c|c|c|c|}
\hline \multirow{2}{*}{ Herbicide $(\mathrm{H})$} & \multicolumn{4}{|c|}{ Days after application (DAA) } \\
\hline & 7 & 14 & 21 & 28 \\
\hline Control & $0.0 \mathrm{c}$ & $0.0 \mathrm{~d}$ & $0.0 \mathrm{e}$ & $0.0 \mathrm{~d}$ \\
\hline Clethodim & $0.0 \mathrm{c}$ & $7.2 \mathrm{c}$ & $14.5 \mathrm{~d}$ & $21.9 \mathrm{c}$ \\
\hline Haloxyfop-p-methyl & $0.0 \mathrm{c}$ & $6.0 \mathrm{c}$ & $24.5 \mathrm{c}$ & $40.1 \mathrm{~b}$ \\
\hline Fomesafen + fluazifop-p-butil $\left(125+125 \mathrm{~g} \mathrm{ha}^{-1}\right.$ a.i. $)$ & $100.0 \mathrm{a}$ & $100.0 \mathrm{a}$ & $100.0 \mathrm{a}$ & $100.0 \mathrm{a}$ \\
\hline Fomesafen + fluazifop-p-butil $\left(187.5+187.5 \mathrm{~g} \mathrm{ha}^{-1}\right.$ a.i. $)$ & $100.0 \mathrm{a}$ & $100.0 \mathrm{a}$ & $100.0 \mathrm{a}$ & $100.0 \mathrm{a}$ \\
\hline Nicosulfuron & $32.6 \mathrm{~b}$ & $65.2 \mathrm{~b}$ & $83.5 \mathrm{~b}$ & $95.5 \mathrm{a}$ \\
\hline$F \operatorname{Test}(H)$ & $8,040.57 * *$ & $1,593.48^{* * *}$ & $768.80 * *$ & $107.46^{* * *}$ \\
\hline \multicolumn{5}{|l|}{ Mineral Oil (MO) } \\
\hline Without & $38.8 \mathrm{a}$ & $44.0 \mathrm{~b}$ & $49.8 \mathrm{~b}$ & $53.1 \mathrm{~b}$ \\
\hline With & $38.8 \mathrm{a}$ & $48.8 \mathrm{a}$ & $57.7 \mathrm{a}$ & $66.1 \mathrm{a}$ \\
\hline$\overline{F \text { Test }(M O)}$ & $0.00^{n s}$ & $23.44 * *$ & $34.44 * *$ & $136.89 * *$ \\
\hline F Test $\left(\mathrm{H}^{*} \mathrm{MO}\right)$ & $0.00^{\mathrm{ns}}$ & $6.31 * *$ & $21.89 * *$ & $79.44 * *$ \\
\hline $\mathrm{CV}(\%)$ & 4.47 & 8.16 & 9.70 & 7.20 \\
\hline
\end{tabular}

Means followed by the same letter within a column are not significantly different by the Tukey test $(\mathrm{p}<0.05) .{ }^{\text {ns Not significant; } *}$ and $* *$ significant at 5 and $1 \%$ respectively.

The interaction between mineral oil and plants with symptoms of phytotoxicity 14 DAA indicated that the mineral oil increases the herbicides haloxyfop-p-methyl and nicosulfuron phytotoxicity. The herbicide fomesafen + fluazifop-p-butil, in all dosages, showed $100 \%$ of plants with symptoms regardless the addition of mineral oil (Table 2).

Without mineral oil, clethodim $(5.0 \%)$ and haloxyfop-p-methyl (1.0\%) showed the same percentage of phytotoxicity compared to control $(0 \%)$. With mineral oil, all herbicides showed higher percentage of crambe plants with symptoms of phytotoxicity, and fomesafen + fluazifop-p-butil (100\% for both dosages) showed the highest values, and clethodim $(9.4 \%)$ and haloxyfop-p-methyl (11.0\%) showed the lowest values between herbicides, but higher when compared to control $(0 \%)$ (Table 2).

The interaction between mineral oil and plants with symptoms of phytotoxicity 21 DAA showed that clethodim and haloxyfop-p-methyl significantly increased the values with mineral 
oil (Table 2). The herbicides fomesafen + fluazifop-p-butil, in two dosages, and nicosulfuron showed not significant increases in relation to the addition of mineral oil, probably by high values of phytotoxicity observed even without mineral oil.

The herbicide fomesafen + fluazifop-pbutil, in two dosages, showed $100 \%$ of plants with symptoms, regardless the addition of mineral oil. Without mineral oil, clethodim and haloxyfop-p-methyl showed significantly the same percentage of phytotoxicity on crambe plants compared to control. With mineral oil, all herbicides showed higher percentages of crambe plants with symptoms of phytotoxicity compared to control, in a way that the two dosages of fomesafen + fluazifop-p-butil showed the highest values, followed by nicosulfuron, haloxyfop-p-methyl, and clethodim, which presented the lowest value (Table 2).

Table 2. Interaction analysis between herbicide and mineral oil for the percentage of Crambe abyssinica plants with visual phytotoxicity by herbicides 14, 21, and 28DAA. Maracaju, MS, Brazil, 2013.

\begin{tabular}{|c|c|c|}
\hline \multicolumn{3}{|c|}{ Phytotoxicity - 14 DAA } \\
\hline \multirow{2}{*}{ Herbicide $(\mathrm{H})$} & \multicolumn{2}{|c|}{ Mineral Oil (MO) } \\
\hline & Without & With \\
\hline Control & $0.0 \mathrm{cA}$ & $0.0 \mathrm{dA}$ \\
\hline Clethodim & $5.0 \mathrm{cA}$ & $9.4 \mathrm{cA}$ \\
\hline Haloxyfop-p-methyl & $1.0 \mathrm{cB}$ & $11.0 \mathrm{cA}$ \\
\hline Fomesafen + fluazifop-p-butil $\left(125+125 \mathrm{~g} \mathrm{ha}^{-1}\right.$ a.i. $)$ & $100.0 \mathrm{aA}$ & $100.0 \mathrm{aA}$ \\
\hline Fomesafen + fluazifop-p-butil $\left(187.5+187.5 \mathrm{~g} \mathrm{ha}^{-1}\right.$ a.i. $)$ & $100.0 \mathrm{aA}$ & $100.0 \mathrm{aA}$ \\
\hline Nicosulfuron & $58.2 \mathrm{bB}$ & $72.2 \mathrm{bA}$ \\
\hline \multicolumn{3}{|c|}{ Phytotoxicity - 21 DAA } \\
\hline \multirow{2}{*}{ Herbicide $(\mathrm{H})$} & \multicolumn{2}{|c|}{ Mineral Oil (MO) } \\
\hline & Without & With \\
\hline Control & $0.0 \mathrm{cA}$ & $0.0 \mathrm{eA}$ \\
\hline Clethodim & $9.4 \mathrm{cB}$ & $19.6 \mathrm{dA}$ \\
\hline Haloxyfop-p-methyl & $5.4 \mathrm{cB}$ & $43.6 \mathrm{cA}$ \\
\hline Fomesafen + fluazifop-p-butil $\left(125+125 \mathrm{~g} \mathrm{ha}^{-1}\right.$ a.i. $)$ & $100.0 \mathrm{aA}$ & $100.0 \mathrm{aA}$ \\
\hline Fomesafen + fluazifop-p-butil (187.5 + $187.5 \mathrm{~g} \mathrm{ha}^{-1}$ a.i. $)$ & $100.0 \mathrm{aA}$ & $100.0 \mathrm{aA}$ \\
\hline Nicosulfuron & $84.0 \mathrm{bA}$ & $83.0 \mathrm{bA}$ \\
\hline \multicolumn{3}{|c|}{ Phytotoxicity - 28 DAA } \\
\hline \multirow{2}{*}{ Herbicide (H) } & \multicolumn{2}{|c|}{ Mineral Oil (MO) } \\
\hline & Without & With \\
\hline Control & $0.0 \mathrm{cA}$ & $0.0 \mathrm{dA}$ \\
\hline Clethodim & $13.8 \mathrm{bB}$ & $30.0 \mathrm{cA}$ \\
\hline Haloxyfop-p-methyl & $9.8 \mathrm{bB}$ & $70.4 \mathrm{bA}$ \\
\hline Fomesafen + fluazifop-p-butil $\left(125+125 \mathrm{~g} \mathrm{ha}^{-1}\right.$ a.i. $)$ & $100.0 \mathrm{aA}$ & $100.0 \mathrm{aA}$ \\
\hline Fomesafen + fluazifop-p-butil (187.5 + $187.5 \mathrm{~g} \mathrm{ha}^{-1}$ a.i. $)$ & $100.0 \mathrm{aA}$ & $100.0 \mathrm{aA}$ \\
\hline Nicosulfuron & $95.0 \mathrm{aA}$ & $96.0 \mathrm{aA}$ \\
\hline
\end{tabular}

Means within a column followed by the same lowercase letter and within a row followed by the same uppercase letter are not significantly different by the Tukey test $(\mathrm{p}<0.05)$.

The interaction between mineral oil and plants with symptoms of phytotoxicity 28 DAA showed that clethodim and haloxyfop-p-methyl significantly increased symptoms with mineral oil. Fomesafen + fluazifop-p-butil, in all dosages, showed $100 \%$ of plants with symptoms regardless the addition of mineral oil. Without mineral oil, fomesafen + fluazifop-p-butil (all dosages) and nicosulfuron showed the highest values, and clethodim and haloxyfop-p-methyl showed the same percentage of plants with symptoms, which were the lowest values among 
herbicides, but significantly higher than control (Table 2). The addition of mineral oil provided an increase on the percentage of plants with symptoms for all herbicides, and fomesafen + fluazifop-p-butil and nicosulfuron showed the highest values, while clethodim showed the lowest values (Table 2).

Regarding the percentage of dead plants with different herbicides was observed in all evaluations that fomesafen + fluazifop-p-butil in all dosages showed $100 \%$ of plants dead. At 7 DAA, clethodim, haloxyfop-p-methyl, and nicosulfuron herbicides caused no mortality to crambe plants. At 14 DAA, was observed that nicosulfuron herbicide caused $8.5 \%$ of mortality, while clethodim and haloxifop-pbuthyl herbicides showed no mortality. At 21 DAA, nicosulfuron showed $66.3 \%$ of mortality, haloxyfop-p-methyl $6.0 \%$, and clethodim showed no mortality of crambe plants. At 28 DAA, nicosulfuron showed $93.0 \%$ of mortality, haloxyfop-p-methyl $17.3 \%$, and clethodim showed no mortality of crambe plants (Table 3).

Table 3. Percentage of Crambe abyssinica plants dead by herbicides 7, 14, 21, and 28 DAA. Maracaju, MS, Brazil, 2013.

\begin{tabular}{|c|c|c|c|c|}
\hline \multirow{2}{*}{ Herbicide $(\mathrm{H})$} & \multicolumn{4}{|c|}{ Days after application (DAA) } \\
\hline & 7 & 14 & 21 & 28 \\
\hline Control & $0.0 \mathrm{~b}$ & $0.0 \mathrm{c}$ & $0.0 \mathrm{~d}$ & $0.0 \mathrm{~d}$ \\
\hline Clethodim & $0.0 \mathrm{~b}$ & $0.0 \mathrm{c}$ & $0.0 \mathrm{~d}$ & $0.0 \mathrm{~d}$ \\
\hline Haloxyfop-p-methyl & $0.0 \mathrm{~b}$ & $0.0 \mathrm{c}$ & $6.0 \mathrm{c}$ & $17.3 \mathrm{c}$ \\
\hline Fomesafen + fluazifop-p-butil $\left(125+125 \mathrm{~g} \mathrm{ha}^{-1}\right.$ a.i. $)$ & $100.0 \mathrm{a}$ & $100.0 \mathrm{a}$ & $100.0 \mathrm{a}$ & $100.0 \mathrm{a}$ \\
\hline Fomesafen + fluazifop-p-butil $\left(187.5+187.5 \mathrm{~g} \mathrm{ha}^{-1}\right.$ a.i. $)$ & $100.0 \mathrm{a}$ & $100.0 \mathrm{a}$ & $100.0 \mathrm{a}$ & $100.0 \mathrm{a}$ \\
\hline Nicosulfuron & $0.0 \mathrm{~b}$ & $8.5 \mathrm{~b}$ & $66.3 \mathrm{~b}$ & $93.0 \mathrm{~b}$ \\
\hline Teste $F(H)$ & $7.11 * *$ & $12,900.17 * *$ & $1,424.13 * *$ & $2,849.29 * *$ \\
\hline Mineral Oil (MO) & & & & \\
\hline Without & $33.3 \mathrm{a}$ & $35.17 \mathrm{a}$ & $44.7 \mathrm{a}$ & $48.7 \mathrm{~b}$ \\
\hline With & $33.3 \mathrm{a}$ & $34.33 \mathrm{a}$ & $46.1 \mathrm{a}$ & $54.8 \mathrm{a}$ \\
\hline F Test $(M O)$ & $1.24^{n s}$ & $1.24^{n s}$ & $1.65^{n s}$ & $61.64 * *$ \\
\hline F Test $\left(\mathrm{H}^{*} \mathrm{MO}\right)$ & $0.33^{\mathrm{ns}}$ & $1.81^{\mathrm{ns}}$ & $4.34 * *$ & $1,325.28^{* * *}$ \\
\hline CV (\%) & 9.25 & 4.06 & 9.07 & 5.82 \\
\hline
\end{tabular}

Means followed by the same letter within a column are not significantly different by the Tukey test $(\mathrm{p}<0.05) .{ }^{\mathrm{n}} \mathrm{Not}$ significant; $*$ and $* *$ significant at 5 and $1 \%$ respectively.

The use of mineral oil showed significantly differences only 28 DAA, when its addition significantly increased the mortality of crambe plants. Furthermore, it was observed significant differences on the interaction between herbicides and mineral oil 21 and 28 DAA (Table 3).

The interaction analysis between mineral oil and mortality 21 DAA showed that the addition of mineral oil did not increase the mortality caused by the herbicides. Fomesafen + fluazifop-p-butil, in all dosages, showed $100 \%$ of mortality regardless mineral oil (Table 4). Without mineral oil, nicosulfuron showed $68.2 \%$ of mortality, and clethodim and haloxyfop-p-methyl showed the same mortality compared to control. With mineral oil, nicosulfuron showed $64.4 \%$ of mortality, haloxyfop-p-methyl $12 \%$, while clethodim and control showed the lowest values (Table 4).

The interaction analysis between mineral oil and mortality 28 DAA showed that the addition of mineral increased the mortality caused by haloxyfop-p-methyl, which showed no mortality without mineral oil and $34.6 \%$ of mortality with mineral oil. Fomesafen + fluazifop-p-butil, in all dosages, showed $100 \%$ of mortality, and nicosulfuron showed a high mortality, reaching more than $90 \%$ regardless the addition of mineral oil (Table 5). Without mineral oil, clethodim and haloxyfop-p-methyl showed the same mortality compared to control, 
while with mineral oil haloxyfop-p-methyl showed $34.6 \%$ of mortality and clethodim and control remained with no mortality (Table 4).

Grain yield showed significantly differences between herbicides. It was observed that clethodim showed the highest value, while haloxyfop-p-methyl and control showed statistically similar values and formed an intermediate group, and fomesafen + fluazifopp-butil, in all dosages, and nicosulfuron showed no grain yield due to the high percentage of mortality, regardless the addition of mineral oil. Furthermore, it was observed that in general, the addition of mineral oil resulted in a significant reduction of grain yield (Table 5).

Table 4. Interaction analysis between herbicide and mineral oil for the percentage of Crambe abyssinica plants dead by herbicides 21 and 28 DAA. Maracaju, MS, Brazil, 2013.

\begin{tabular}{|c|c|c|}
\hline \multicolumn{3}{|c|}{ Percentage of dead plants - 21 DAA } \\
\hline \multirow{2}{*}{ Herbicide $(\mathrm{H})$} & \multicolumn{2}{|c|}{ Mineral Oil (MO) } \\
\hline & Without & With \\
\hline Control & $0.0 \mathrm{cA}$ & $0.0 \mathrm{dA}$ \\
\hline Clethodim & $0.0 \mathrm{cA}$ & $0.0 \mathrm{dA}$ \\
\hline Haloxyfop-p-methyl & $0.0 \mathrm{cA}$ & $12.0 \mathrm{cA}$ \\
\hline Fomesafen + fluazifop-p-butil $\left(125+125 \mathrm{~g} \mathrm{ha}^{-1}\right.$ a.i. $)$ & $100.0 \mathrm{aA}$ & $100.0 \mathrm{aA}$ \\
\hline Fomesafen + fluazifop-p-butil $\left(187.5+187.5 \mathrm{~g} \mathrm{ha}^{-1}\right.$ a.i. $)$ & $100.0 \mathrm{aA}$ & $100.0 \mathrm{aA}$ \\
\hline Nicosulfuron & $68.2 \mathrm{bA}$ & $64.4 \mathrm{bA}$ \\
\hline \multicolumn{3}{|c|}{ Percentage of dead plants - 28 DAA } \\
\hline \multirow{2}{*}{ Herbicide } & \multicolumn{2}{|c|}{ Mineral Oil } \\
\hline & Without & With \\
\hline Control & $0.0 \mathrm{cA}$ & $0.0 \mathrm{dA}$ \\
\hline Clethodim & $0.0 \mathrm{cA}$ & $0.0 \mathrm{dA}$ \\
\hline Haloxyfop-p-methyl & $0.0 \mathrm{cB}$ & $34.6 \mathrm{cA}$ \\
\hline Fomesafen + fluazifop-p-butil (125 + $125 \mathrm{~g} \mathrm{ha}^{-1}$ a.i. $)$ & $100.0 \mathrm{aA}$ & $100.0 \mathrm{aA}$ \\
\hline Fomesafen + fluazifop-p-butil (187.5 + $187.5 \mathrm{~g} \mathrm{ha}^{-1}$ a.i. $)$ & $100.0 \mathrm{aA}$ & $100.0 \mathrm{aA}$ \\
\hline Nicosulfuron & $92.0 \mathrm{bA}$ & $94.0 \mathrm{bA}$ \\
\hline
\end{tabular}

Means within a column followed by the same lowercase letter and within a row followed by the same uppercase letter are not significantly different by the Tukey test $(\mathrm{p}<0.05)$.

Without mineral oil was observed that clethodim and haloxyfop-p-methyl showed the same values of grain yield $(1,207.0$ and $1,120.0$ respectively), while control showed a lower value $(1,053.9)$ (Table 5). Herbicides with mineral oil indicated that clethodim showed the highest value $(1,210.4)$, followed by control (984.3), and haloxyfop-p-methyl (803.5) (Table 5 ). It is possible to observe that the addition of mineral oil on haloxyfop-p-methyl reduced grain yield, indicating that this herbicide should be used without mineral oil.

In general, mineral oil increased the phytotoxic effects of herbicides on crambe plants when sprayed on post-emergence. The mineral oil addition on haloxyfop-p-methyl increased the phytotoxicity to crambe plants. The herbicide fomesafen + fluazifop-p-butil and nicosulfuron were harmful to crambe plants with or without mineral oil, and clethodim (with and without mineral oil) and haloxyfop-pmethyl (without mineral oil) were harmless to crambe plants and can be used on postemergence.

The results obtained in this study indicated that crambe is a sensitive crop to herbicides used on post-emergence. Oliveira Neto et al. (2011) also observed that trifluralin was harmless to crambe when used on postemergence at doses lower than $450 \mathrm{~g} \mathrm{ha}^{-1}$ a.i., and alachlor and pendimethalin, even in low doses, resulted in high phytotoxicity and marked reduction in the number of plants. Similar study conducted by Souza et al. (2014) showed that clefoxydim + fenoxaprop-p-ethyl, fluazifop-pbutil, quinclorac, setoxydim and clefoxydim 
applied on post emergence were harmless to crambe plants.

The addition of mineral oil can increase the phytotoxic effects of herbicides on crambe plants. However, it is recommended for many herbicides to reduce the surface tension, enabling improvements in herbicide absorption, reducing possible losses, and hence optimization of weed management practices (Mendonça et al. 2007).

Table 5. Grain yield ${ }^{1}\left(\mathrm{~kg} \mathrm{ha}^{-1}\right)$ of Crambe abyssinica treated with different herbicides with and without mineral oil. Maracaju, MS, Brazil, 2013.

\begin{tabular}{lccc}
\hline \multicolumn{1}{c}{ Herbicide $(\mathrm{H})$} & \multicolumn{2}{c}{ Mineral Oil (MO) } & \multirow{2}{*}{ Average } \\
\cline { 2 - 3 } & Without & With & \\
\hline Control & $1,053.9 \mathrm{bA}$ & $984.3 \mathrm{bA}$ & $1,019.1 \mathrm{~b}$ \\
Clethodim & $1,207.0 \mathrm{aA}$ & $1,210.4 \mathrm{aA}$ & $1,208.7 \mathrm{a}$ \\
Haloxyfop-p-methyl & $1,120.0 \mathrm{aA}$ & $803.5 \mathrm{cB}$ & $961.7 \mathrm{~b}$ \\
Fomesafen + fluazifop-p-butil $\left(125+125 \mathrm{~g} \mathrm{ha}^{-1}\right.$ a.i.) & $0.0 \mathrm{cA}$ & $0.0 \mathrm{dA}$ & $0.0 \mathrm{c}$ \\
Fomesafen + fluazifop-p-butil $\left(187.5+187.5 \mathrm{~g} \mathrm{ha}^{-1}\right.$ a.i.) & $0.0 \mathrm{cA}$ & $0.0 \mathrm{dA}$ & $0.0 \mathrm{c}$ \\
Nicosulfuron & $0.0 \mathrm{cA}$ & $0.0 \mathrm{dA}$ & $0.0 \mathrm{c}$ \\
\hline Average & $563.4 \mathrm{~A}$ & $499.7 \mathrm{~B}$ & \\
\hline F Test (Herbicide) & & $995.99^{* *}$ & \\
F Test (Mineral Oil) & & $17.57^{* *}$ & \\
F Test (Herbicide * Mineral Oil) & & $11.61^{* *}$ & \\
CV $(\%)$ & & 11.08 & \\
\hline
\end{tabular}

Means within a column followed by the same lowercase letter and within a row followed by the same uppercase letter

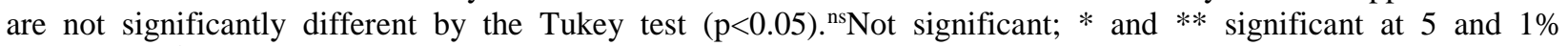
respectively. ${ }^{1}$ Grain humidity adjusted to $13 \%$.

Grigolli et al. (2011) observed that the addition of mineral and vegetal oils enhanced the mesotrione herbicide control of Euphorbia heterophylla plants with different nozzles. Furthermore, the authors verified that higher dosages of mineral oil (3.0\%) increased the effective control of the weed.

It is evident that the use of herbicides without mineral oil can reduce the application efficiency. Thus, it is necessary to combine efficiency with selectivity of herbicides, aiming weed management on crambe crop. Thus, studies are needed in order to verify the efficiency of the application on weed control without the mineral oil. The present study also points out the way for new researches concerning selectivity of post-emergence herbicides on crambe plants.

\section{Conclusions}

Clethodim (with and without mineral oil) and haloxyfop-p-methyl (without mineral oil) herbicides are harmless to crambe plants and can be used on post-emergence. Mineral oil can increase the phytotoxic effects of the herbicides on crambe plants.

\section{References}

Broch, D.L.; Roscoe, R. Fertilidade do solo, adubação e nutrição do crambe. In: Pitol, C.; Broch, D.L.; Roscoe, R. (Ed.). Tecnologia e produção: Crambe. Maracaju: Fundação MS, 2010. p.22-36.

Carneiro, S.M.T.P.G.; Romano, E.; Marianowski, T.; Oliveira, J.P.; Garbim, T.H.S.; Araújo, P.M. Ocorrência de Alternaria brassicicola em crambe (Crambe abyssinica) no estado do Paraná. Summa Phytopathology, v.35, n.2, p.154-155, 2009.

Chhikara, S.; Duttaa, I.; Paulosea, B.; Jaiwalb, P.K.; Dhankher, O.P. Development of an Agrobacterium-mediated stable transformation method for industrial oilseed crop Crambe abyssinica 'BelAnn'. Industrial Crops and Products, v.37, n.1, p.457-465, 2012. 
Endres, G.; Schatz, B. Crambe Production, 1993 Disponível <http://www.ag.ndsu.edu/pubs/plantsci/crops/a 1010w.htm\#weed>. Acesso em 22 jan 2014.

Fontana, F.; Lazzeri, L.; Malaguti, L.; Galletti, $\mathrm{S}$. Agronomic characterization of some Crambe abyssinica genotypes in a locality of the Po Valley. European Journal of Agronomy, v.9, n.2-3, p.117-126, 1998.

Grigolli, J.F.J.; Pereira, F.C.M.; Peñaherrera, L.C.; Santos, E.A.; Ferreira, M.C. Controle de Euphorbia heterophylla com mesotrione e óleos para diferentes pontas de pulverização. Revista Brasileira de Herbicidas, v.10, n.3, p.266-276, 2011.

Jasper, S.P.; Biaggioni, M.A.M.; Silva, P.R.A.; Seki, A.S.; Bueno, O.C. Análise energética da cultura do crambe (Crambe abyssinica Hochst.) produzida em plantio direto. Engenharia Agrícola, v.30, n.3, p.395-403, 2010.

Li, X.; Fan, J.; Gruber, J.; Guan, R.; Frentzen, M.; Zhu, L.H. Efficient selection and evaluation of transgenic lines of Crambe abyssinica. Frontiers in Plant Science, v.4, n.162, p.1-9, 2013.

Mendonça, C.G.; Raetano, C.G.; Mendonça, C.G. Tensão superficial estática de soluções aquosas com óleos minerais e vegetais utilizados na agricultura. Engenharia Agrícola, v.27, n2, p.16-23, 2007.

Oliveira Neto, A.M.; Guerra, N.; Maciel, C.D.G.; Silva, T.R.B.; Lima， G.G.R. Seletividade de herbicidas aplicados em préemergência na cultura do crambe. Revista Brasileira de Herbicidas, v.10, n.1, p.49-56, 2011.

Roscoe, R.; Pitol, C.; Broch, D.L. Necessidades climáticas e ciclo da cultura. In: Pitol, C.; Broch, D.L.; Roscoe, R. (Ed.). Tecnologia e produção: Crambe. Maracaju: Fundação MS, 2010. p.7-9.

Silva, F.A.S.; Azevedo, C.A.V. Versão do programa computacional Assistat para o sistema operacional Windows. Revista Brasileira de Produtos Agroindustriais, v.4, n.1, p.71-78, 2002.

Souza, G.S.F.; Vitorino, H.S.; Fioreze, A.C.C.L.; Pereira, M.R.R.; Martins, D. Seletividade de herbicidas na cultura do crambe. Semina Ciências Agrárias, v.35, n.1, p.161168, 2014.

Stougaard, R.N.; Moomaw, R.S. Crambe (Crambe abyssinica) tolerance to herbicides. Weed Technology, v.5, n.3, p.566-569, 1991. 